\title{
Vezetési stílusok egykor és most
}

\author{
S. SZABOLCSI \\ Debreceni Egyetem Gazdaságtudományi Kar, Vezetés- és Szervezéstudományi Intézet, \\ szabolcsi.sara@econ.unideb.hu
}

Absztrakt. A vezetéstudomány eredményeit fokozott érdeklődés övezi 105 éves történelme során. A vezetési stílus vizsgálata egy, a mai napig aktuális megközelítési módja a vezetéskutatásnak. Jelen cikkemben ezen megközelítés eddigi eredményeit adom közre: bemutatom a „klasszikus” vezetési stílusmodelleken túl az új irányzatokat is. A „klasszikus” modellek közül a döntésközpontú, a személyiségközpontú, és a kontingencialista modelleket veszem sorra. Az "új” irányzatok közül bemutatásra kerül a nőies és a férfias vezetési stílus, az üzletkötő és az átalakitó vezetés, valamint a participatív vezetési stílus. A cikkben összefoglalom a vezetési stílusra ható külsô és belső tényezóket, az ezzel kapcsolatos kutatások eredményeit is közreadva.

Abstract. The throughputs of Management sciences have always been in the middle of interest for its 105 years long history. Analysing the management styles is a prospering and actual scientific approach of leadership research. In the following, I present the throughputs of the researches which are applying this approach: I introduce both the „classical"management style models and the new ones. As for, classical"models, I introduce the decision-making oriented typologies, the personality oriented typologies and the situational leadership theories. By "new"theories I introduce the feminin and masculin management styles, the transactional and the transformational leadership and the participative management style. In the article I summarize the internal and external factors that influence the management style, and the same time introduce the outcomes of researches studying the topic.

\section{Témafelvetés}

Amióta az ember csoportba verődött és közösségben él a vezetés hagyományosan pozíción és a tekintélyen, gazdasági, politikai és katonai tényezőkön alapult, a tevékenység vezérelve pedig az érdekérvényesítés volt (Purebl, 2013).

A XX. század elejétől a vezetéstudomány egy olyan interdiszciplináris tudományággá nőtte ki magát, ami ugyan még csak 105 éves, de létezése óta eredményeit hatalmas érdeklődés övezi, s rövid történetéhez viszonyítva komoly fejlődést tud felmutatni.

A tudomány születésekor művelői elsősorban a vállalati élet megszervezésének mikéntjére helyezték a hangsúlyt. Az klasszikus szerzők a részletekbe menő munkamegosztással és a szabályozottság eszközeivel igyekeztek olyan szervezeti kereteket teremteni, amelybe ha belehelyezik az egyént, az csak jól tud teljesíteni. A szervezeti hatékonyságot a rendszerben keresték, nem az emberben (Bakacsi, 2001). Ez a nézőpont az idők során megváltozott, mára épp ellenkezőképpen gondolkodunk: vizsgálatok középpontjában a szervezetben munkálkodó ember áll. 
A szervezetben dolgozó emberek egy - a kutatások szempontjából is - kiemelt csoportja a vezetők csoportja, mivel az ő tevékenységük nagymértékben kihat a többiek munkájára.

A vezetők vizsgálatának homlokterében a 40-50-es években még a vezetőket jellemző tulajdonságok álltak. A kutatók a „jó vezető titkát” keresve megpróbálták összegyűjteni a tulajdonságok azon csoportját melyek a sikeres vezetőket jellemezték. Abban bíztak, hogy egy megfelelő tulajdonságcsoport összegyűjtésével a későbbiekben egyszerűbbé válhat a vezetők kiválasztása - aki bírja ezen tulajdonságokat, abból jó vezető lesz, aki nem abból nem. Az akkori vizsgálatok ellentmondásos eredményei megkérdőjelezték ennek a szemléletnek a helyességét, így a későbbiekben az ideális tulajdonságok kutatása helyett, a vezetői magatartásminták kerültek az érdeklődés középpontjába ezen magatartásminták vezetési stílusokként váltak ismertté (Bakacsi, 2001; Klein 2002). A vezetési stílus vizsgálata egy, a megjelenése óta örökzöldnek - s így a mai napig is aktuálisnak - számító tudományos megközelítési módja a vezetéskutatásnak.

Jelen cikk célja a vezetési stílusok irodalmának feldolgozásával a vezetési stílusok és stílusmodellek átfogó bemutatása, értelmezése.

\section{Mi a vezetési stílus?}

Klein (2002) szerint a vezetési stílus a vezető mások által érzékelt viselkedésmintája. Dobák (2006) definíciója alapján „a vezetési stílus alapvetően a fölöttes és a beosztott közötti interakciókat jellemzi; azt a kapcsolatrendszert, amelyből megállapítható, hogy mekkora a vezetés és a beosztottak úgynevezett döntési játéktere, valamint milyenek a vezetőknek a személyiségjegyei." Dobák és Antal (2013) alapján a vezetési stílus „az a mód, ahogy a vezető közvetlenül és személyesen hat a beosztottakra annak érdekében, hogy az egyéni és szervezeti célokat összehangolja.".

Dienesné és Berde (2003) értelmezése szerint „a vezetési stílus a hatalomgyakorlás módját jelenti és magába foglalja mindazoknak az eszközöknek és módszereknek az együttesét, amelyekkel a vezetők hatást gyakorolnak munkatársaikra."

Megítélésem szerint ez utóbbi definíció tükrözi legjobban a vezetési stílust, ugyanakkor tág teret hagyva a kutatói értelmezésnek.

A vezetési stílus és a vezetői stílus, vagy a vezető stílusa szinonim fogalmak, cikkemben felváltva használom őket. 


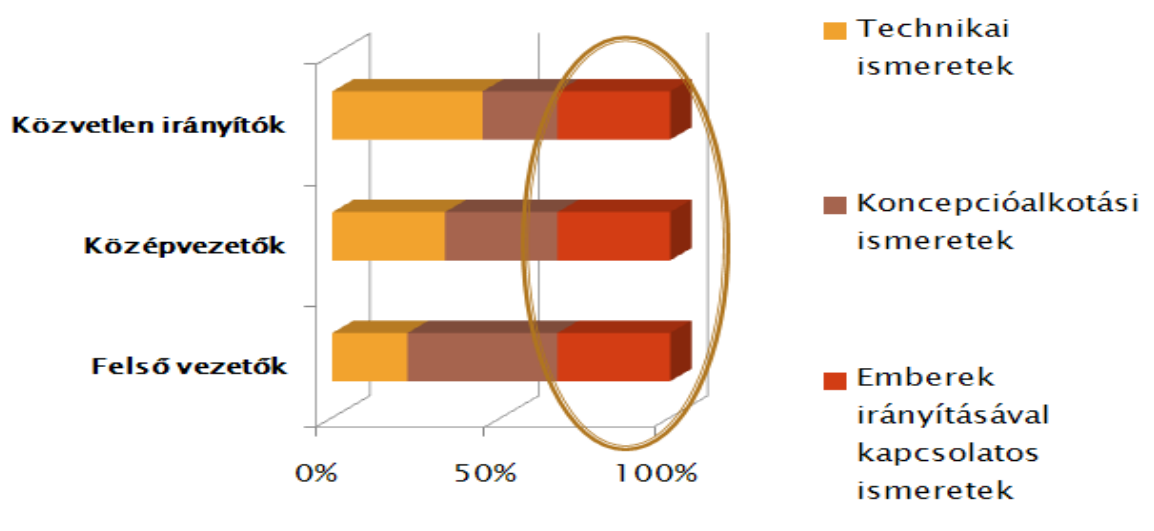

1. ábra: A különböző vezetési szinteken szükséges képességek

(Forrás: Kelly-Grimes, 1993)

Az ábrán jól látszik, hogy az emberekkel való bánás képessége mindegyik vezetési szinten egyaránt jelentős súlyt képvisel - az ábra jól érzékelteti az emberekkel való bánás, és így a vezetési stílus jelentőségét.

\section{A “klasszikus" vezetési stílusmodellek - döntésközpontú, személyiségközpontú és kontingencialista elméletek}

A vezetési stílusok tárgyalását a legtöbb szakkönyv időrendiségében mutatja be, ezáltal bemutatva a stíluselméletek fejlődéstörténetét - erre a logikára épül jelen bemutatás is.

\subsection{Döntésközpontú stílusmodellek}

A döntésközpontú modellek a vezetési stílusokat a vezető döntéshozatali módja alapján tipologizálják. Azt vizsgálják, hogy az egyes vezetők mennyire vonják be beosztottjaikat a döntési folyamatba. Az alaptipológiákat Lewin híres kísérletsorozata nyomán határozhatjuk meg: megkülönböztetünk autokratikus, demokratikus és laissez faire (más néven liberális) stílusokat. Az autokratikus vezető egyedül dönt minden lényeges kérdésben, a feladatokat részletesen kijelöli, utasít, irányít, a csoporttagokat szubjektíven értékeli. A demokratikus vezető a hangsúlyt a csoporttagok csoporttevékenységbe való bevonására helyezi, a döntésekbe bevonja a csoporttagokat, objektív teljesítményértékelésre törekszik. A liberális vezető a kísérletben nem kezdeményez, nem jelöl ki irányokat, a csoportot majdhogynem magára hagyja, csak kérés esetén segít.

Lewin (1975) eredményei alapján arra a következtetésre jutott, hogy a csoporttagok az autokratikus vezetővel szemben mind a demokratikus stílusú, mind a liberális vezetőt vonzóbbnak találták. Az autokratikus vezető mellett szólhat látszólag a magasabb csoportteljesítmény, ez a teljesítmény ugyanakkor negatív csoporthangulattal és a csoporttagok belső motivációjának hiányával párosul. A demokratikus vezetés mellett szól a jó csoporthangulat, a nagyfokú kreativitás és a csoporttagok belső motivációjának magas szintje. A liberális stílus előnyöket csak abban az esetben tud felmutatni, ha 
nagyon fejlett - önmagának célokat kijelölni, s magát motiválni képes - beosztottak esetén alkalmazzuk.

Likert (1974) modelljében négy stíluskategóriát határoz meg, a csoportosítás szempontja a beosztottak részvételének mértéke a vezetési folyamatban. Likert kategóriái az alábbiak: keménykezű parancsoló, jóakaratú parancsoló, konzultatív stílusú vezető és vezető részvételi csoportban. A keménykezű és a jóakaratú parancsoló lényegében megfeleltethető Lewin autokratikus kategóriájának, a két stílus közötti különbség - ahogyan azt elnevezése is sugallja - a vezető motivációs módszerében jelentkezik: míg a keménykezű parancsoló a fenyegetés és büntetés mellett ritkán él a jutalmazás lehetőségével, addig a jóakaratú parancsoló éppen fordítva: lehetőség szerint jutalmaz. A konzultatív vezetési stílus átmenetet képez az autokratikus és a demokratikus stílus között, a vezető bizalmat tanúsít a beosztottak iránt, részvételt biztosít számukra a döntési folyamatokban, kikéri a véleményüket. A részvételi csoport vezetője megfeleltethető Lewin demokratikus stílusú vezetőjének: bízik beosztottjaiban, véleményüket kikéri, ötleteiket konstruktívan felhasználja, a motivációnak eleme a csoporttagok részvételének biztosítása a közös célok kijelölésében és a teljesítményértékelésben. Likert és munkatársai eredményeik alapján ez utóbbi vezetési stílust ajánlották a vezetés hatékonyságának növelésére.

Tannenbaum és Schmidt hétfokozatú skálán írták le és értelmezték a beosztottak részvételét a hatalomban. A skála két végén álló két szélsőség a főnökközpontú és a beosztottközpontú vezetési stílus.

A hét fokozat a következő:

1. A vezető meghozza és bejelenti döntését.

2. A vezető „eladja” döntését.

3. A vezető elmondja gondolatait, és felszólítja beosztottjait, hogy tegyenek fel kérdéseket.

4. A vezető bejelent egy döntést úgy, hogy azon még változtatni lehet.

5. A vezető előadja a problémát, meghallgatja a javaslatot, majd dönt.

6. A vezető megállapítja a határokat és felkéri a csoportot a döntés meghozatalára.

7. A vezető lehetővé teszi, hogy előírt korlátokon belül a csoport hozza meg a döntéseket. (Tannenbaum - Schmidt, 1966)

\subsection{Személyiségközpontú stílusmodellek}

Személyiségközpontúnak nevezzük azokat az elméleteket, amelyeknél a tipologizálás alapismérvei a vezető személyisége, személyiségjegyei, figyelmének irányultsága (Bakacsi, 2001). A figyelem irányultsága szempontjából a következőkben bemutatott csoportosítások alapján két fó irány körvonalazható: a vezető vagy a feladatra koncentrál, vagy a munkatársakkal való jó kapcsolat kialakítására és fenntartására.

A Michigani Egyetem modellje alapján két vezetői stílus különíthető el: a feladatcentrikus és a beosztottcentrikus. A feladatcentrikus vezető számára a teljesítmény a legfontosabb. A biztosan magas teljesítmény érdekében a beosztottjai számára részletesen előírja a feladatokat és végrehajtásuk 
mikéntjét, munkatársait szoros felügyelet alatt tartja. A beosztottcentrikus vezető figyelme a munkatársakra irányul, a jól összetartó csoport kialakításán fáradozik, fontos számára hogy a munkatársai elégedettek legyenek, ennek érdekében teret biztosít számukra a fejlődésre és bevonja őket a döntéshozásba, lazább ellenőrzést tart fenn. A modell következtetései alapján a két stílus kizárja egymást - tehát nincs stíluskeveredés, ötvöződés - valamint arra is rámutattak, hogy a beosztottcentrikus vezetési stílus általában eredményesebb, mint a feladatcentrikus (Klein, 2002).

Az Ohiói Állami Egyetem modellje a vezetői stílusok két fő típusát „kezdeményezés-struktúrálás”-ként és „figyelem”-ként nevezi meg. A modell nagyfokú hasonlóságot mutat a Michigani Egyetem modelljével. A „kezdeményezés-struktúrálás” mint vezetői stíluskategória megfeleltethető az előzőekben bemutatott feladatcentrikus stílusnak; ugyanakkor a „figyelem” kategória megfeleltethető a beosztottcentrikus stílusnak.

A modell azonban - a Michigani Egyetem modelljével ellentétben - nem tartja egymást kizárónak a két stílus meglétét egy vezető személyén belül. Az Ohiói Állami Egyetem kutatói arra a következtetésre jutottak, hogy azok a vezetők eredményesebbek, aki nagymértékben hajlamosak a „figyelem” vezetési stílus gyakorlására - ez egybecseng a Michigani Egyetem kutatóinak következtetésével. Ugyanakkor kiemelték, hogy a legeredményesebb vezetők mindkét általuk definiált vezetési stílust egyszerre alkalmazták (tehát mindkét dimenzió mentén jól teljesítettek). (Klein, 2002)

Blake-Mouton (1978) az előbbiekben bemutatott két kategória mentén rácsmodellt alkotott. Osztva az Ohiói modell álláspontját, miszerint egy vezető minkét dimenzió (feladat-központúság és beosztottközpontúság) elemeit ötvözheti vezetési stílusában, a 81 mezőből álló modelljében 81 vezetési stílust határozott meg, annak függvényében, hogy melyik dimenzió mennyire jellemzi az adott vezetőt. A 81 lehetséges kombinációból a modell alkotói 5 „nevezetes” pontot emeltek ki, mint legjellemzőbb értékeket. Az 5 pontot a koordináta rendszer sarokpontjai és középső pontja adja, a pontokhoz társul egy-egy vezetési stílus:

1. Csoportközpontú vezetés: A vezető egyaránt nagymértékben figyel a termelési célok elérésére és a beosztottak ,jól-létére”. A munkateljesítmény forrása az elkötelezett ember. A szervezeti célhoz kapcsolódó csoportcélok, a csoporttagok közötti erős egymásrautaltság és magas fokú bizalom jellemzi.

2. Emberközpontú vezetés: A vezető kiemelt figyelmet fordít a munkatársaira, a munkahelyi jó légkör kialakítására, ugyanakkor minimális figyelmet a termelésre. Baráti légkört és kellemes munkatempót eredményez.

3. Kompromisszumos vezetés: Ez a stílus az arany középutat jelöli ki. A vezető „kello”” mértékben figyel oda a termelésre és a beosztottakra is, ezáltal általában „megfelelő” eredményt tud elérni.

4. Hatalom-engedelmesség: A vezető minden figyelmét a termelésre fordítja, a humán szempontok háttérbe szorulnak.

5. „Fél-vezetés”: a vezető minimális erőfeszítést tesz a munka elvégzésére, és pusztán szervezeti tagsága megtartása erejéig figyel oda a munkatársaira. (Bakacsi, 2001) 


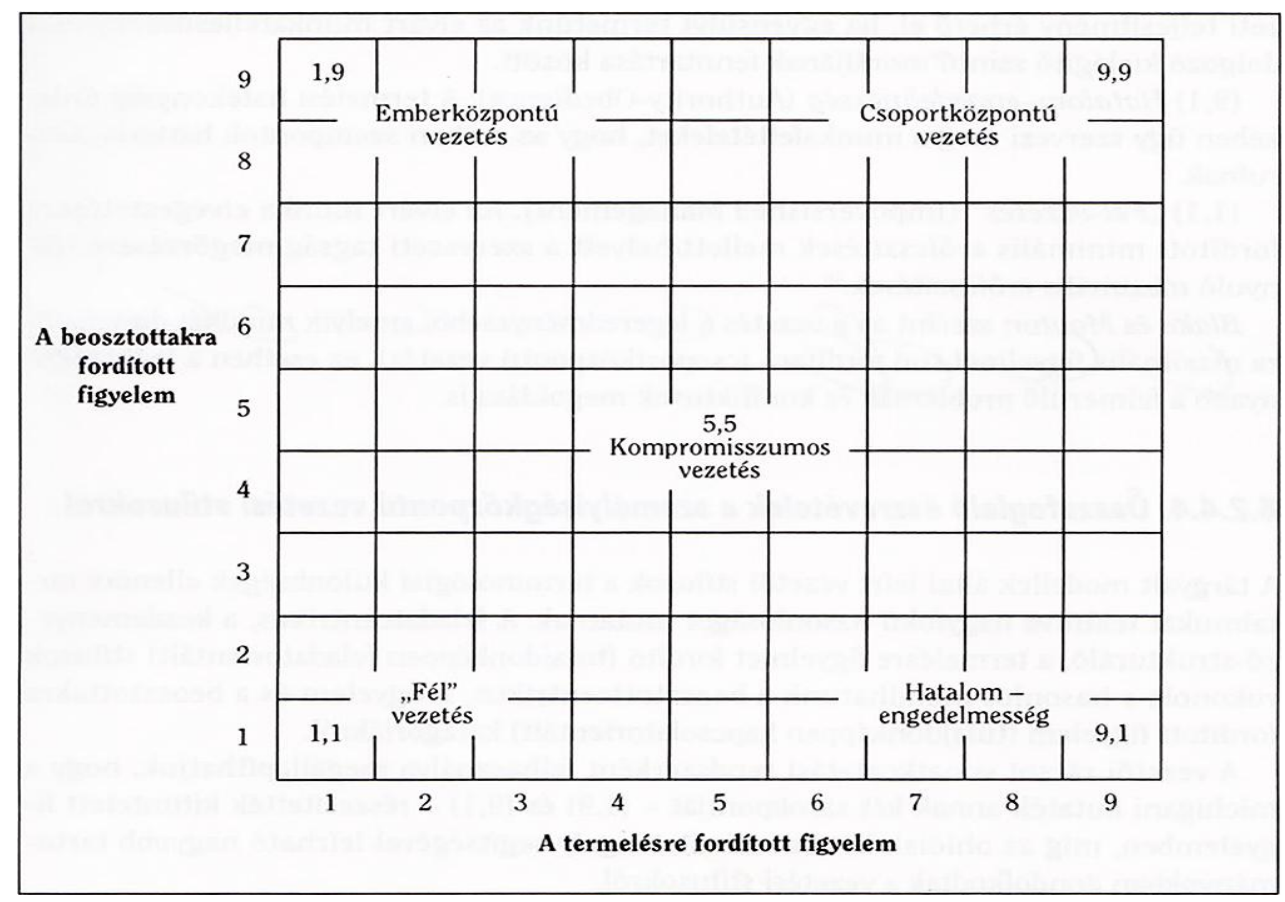

2. ábra: Blake és Mouton rácsmodellje (1978), rajta az öt stílussal

Blake és Mouton a csoportközpontú vezetést nevezi meg, mint leghatékonyabb vezetési stílust.

\subsection{Kontingencialista stílusmodellek}

A kontingencialista vagy más néven szituációs modellek szemléletbeli változást jelentenek az eddig bemutatottakhoz képest. Céljuk - ellentétben az eddig már bemutatott döntésközpontú és személyiségközpontú stílusmodellekkel - nem az egyedüli, leghatékonyabb stílusnak a meghatározása, hanem a lehetséges stílusváltozatok hozzárendelése a vezetési szituáció különböző változataihoz. A következőekben bemutatott modellek tehát eltérnek ugyan abban a tekintetben, hogy döntésközpontú vagy személyiségközpontú megközelítést alkalmaznak-e, továbbá abban, hogy a vezetési stílusra pontenciálisan ható külső tényezők közül melyeket emelik be modelljükbe, azonban egyeznek a szemléletben: az „egyetlen üdvözítő” stílus helyett a különböző helyzetekben ajánlható stílusok gyűjteményét adják közre.

Vroom és Yetton (1973) normatív modelljükben döntésközpontú megközelítést alkalmaznak. Azt vizsgálják, hogy a vezetőnek milyen esetekben milyen mértékű beleszólást célszerű biztosítania a beosztottaknak a döntéshozatalba. A vezetőt az adott helyzetnek megfelelő stílus kialakításában egy döntési fa segíti. A fa nyolc kérdésére adott igen vagy nem válaszok alapján a modell ötféle vezetési stílust ajánl. A kérdések olyan logikus felvetéseket tartalmaznak, mint: Rendelkezik-e a vezető a döntés meghozatalához szükséges információkkal?, A beosztottak vajon rendelkeznek-e fontos többletinformációkkal?, Mennyire szükséges a konszenzusos döntés ahhoz, hogy a megvalósítás zökkenőmentes legyen a későbbiekben?, A beosztottak bevonása esetén lehet-e számítani konstruktív, és nem kizárólag csak önérdeküket követő részvételükre?, stb. 
A szerzőpáros ötféle stílust különböztet meg annak mentén, hogy a beosztottaknak mekkora beleszólásuk van a döntésekbe: két autokratikus, két konzultatív és egy demokratikus stílust.

Fiedler (1980) kontingencia-modellje személyiségközpontú megközelítést alkalmaz. Kétfajta vezetési stílust különböztet meg: feladatorientált és kapcsolatorientált stílust. Fiedler a stílust a személyiségben mélyen gyökerező tényezőnek tartja, és a Michigani Egyetem kutatóihoz hasonlóan úgy véli, hogy egy vezető vagy az csak egyik, vagy csak a másik stílust alkalmazza. Modelljében három szituációs változót vesz figyelembe, mindegyik változóhoz két alternatívát rendelve: a vezető és a beosztottak kapcsolatát (jó vagy rossz), a feladat struktúráltságát (struktúrált vagy struktúrálatlan) és a vezető pozíciójából fakadó hatalmát (erős vagy gyenge). A három tényező összesen nyolc kombinációt eredményez, tehát nyolc szituációt ír le, melyekben más- más vezetési stílus vezethet jó csoportteljesítményhez.

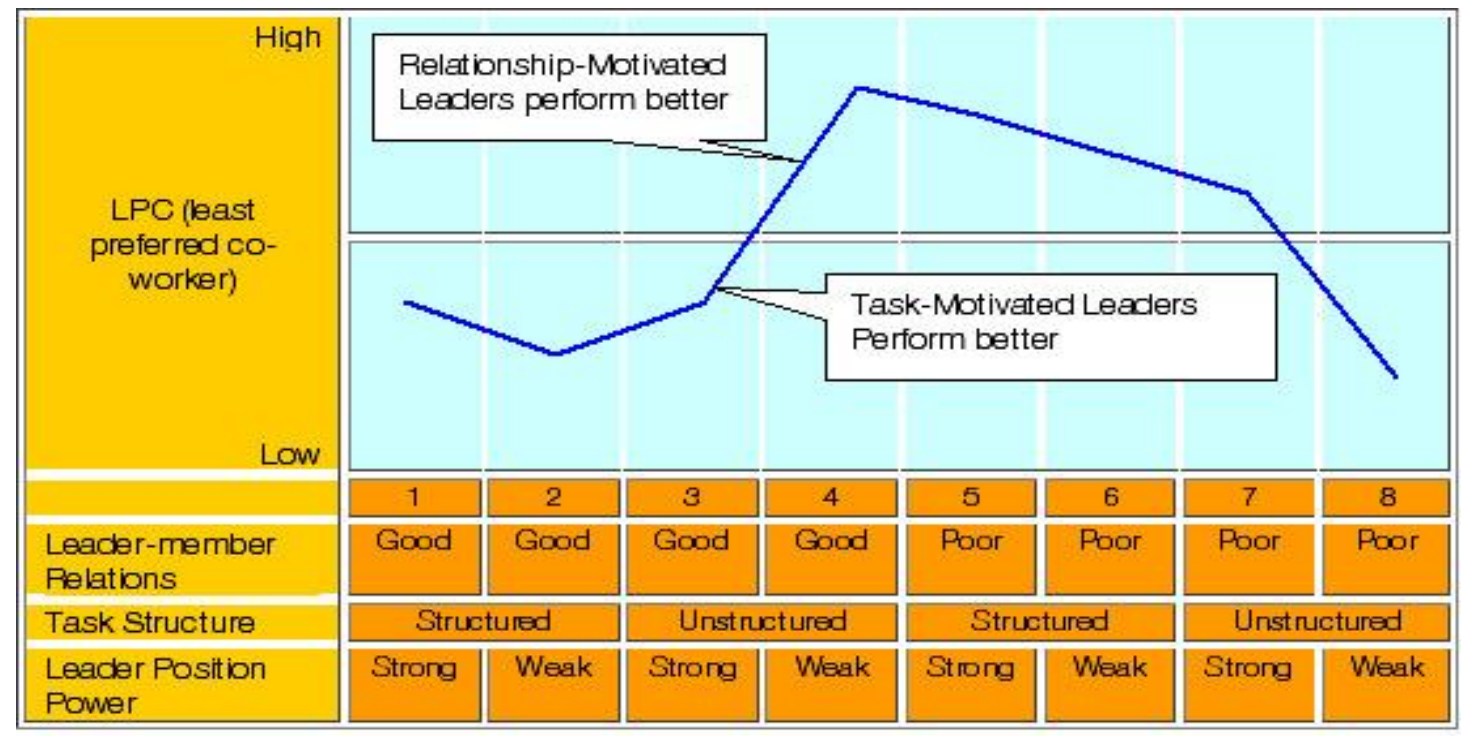

3. ábra: Fiedler kontingencia-modellje (1980)

Az ábráról jól leolvasható, hogy az egyes esetekben milyen stílus vezet eredményre. Látható, hogy a vezető számára legkedvezőbb és legkedvezőtlenebb helyzetekben a feladatorientált vezetés a célravezető, ugyanakkor a „köztes” helyzetekben a kapcsolatorientált vezető teljesít jobban.

Fiedler modelljének érdekessége, hogy - mivel a stílust a személyiségben mélyen gyökerező tényezőnek tartja - nem hisz abban, hogy a vezető a szituációhoz igazodóan tudja változtatni stílusát. Ajánlása alapján egy nem megfelelő vezetési stílus - szituáció párosítás fennállása esetén vagy a szituációt kell megváltoztatni, vagy a vezetőt kell leváltani.

Hersey és Blanchard (1982) szituációs modelljében a független változó a követők személyiségének érettsége: tehát hogy mennyire képesek illetve mennyire hajlandóak feladataik önálló elvégzésére. A szerzőpáros a már bemutatott kapcsolatorientáció és feladatorientáció dimenziók mentén négy vezetési stílust határoz meg: 
1. A rendelkező stílust magas feladat orientáció és alacsony kapcsolat orientáció jellemzi. Éretlen (az ábrán M1-gyel jelölt) beosztottal való együttmúködés során alkalmazható - például újonnan belépő dolgozók esetében. A stílust a világos, egyértelmű utasítások jellemzik.

2. A meggyőző stílust magas feladat- és kapcsolat orientáció jellemzi. A beosztott érettségét a magas motivációs szint mellett a feladat önálló megvalósítását illető bizonytalanság jellemzi (M2 képtelen, de hajlandó vagy motivált), a még nem eléggé tapasztalt, kezdő dolgozók lehetnek ilyenek. A stílus kétirányú kommunikációra, a motivációra épül, igyekszik bizalmat ébreszteni a beosztottban. A döntéseket és az ellenőrzést azonban a vezető saját kezében tartja.

3. Az együttműködő stílust magas kapcsolat orientáció és alacsony feladat orientáció jellemzi. A beosztottakra kellően érettek, képesek önállóan is megfelelő döntéseket hozni, azonban még kissé bizonytalanok (M3 szintű érettség). Az együttműködő stílus esetén a vezető és a csapat megosztja a döntés felelősségét.

4. A delegáló stílust egyaránt alacsony feladat- és kapcsolat orientáció jellemzi. A beosztottakat magas fokú érettség (M4) jellemzi, tehát képesek, és akarnak is önállóan dolgozni. A delegáló stílus esetében lehet, hogy a vezető határozza meg a problémát, de a megoldás módja a beosztottakra van bízva (Klein, 2002).

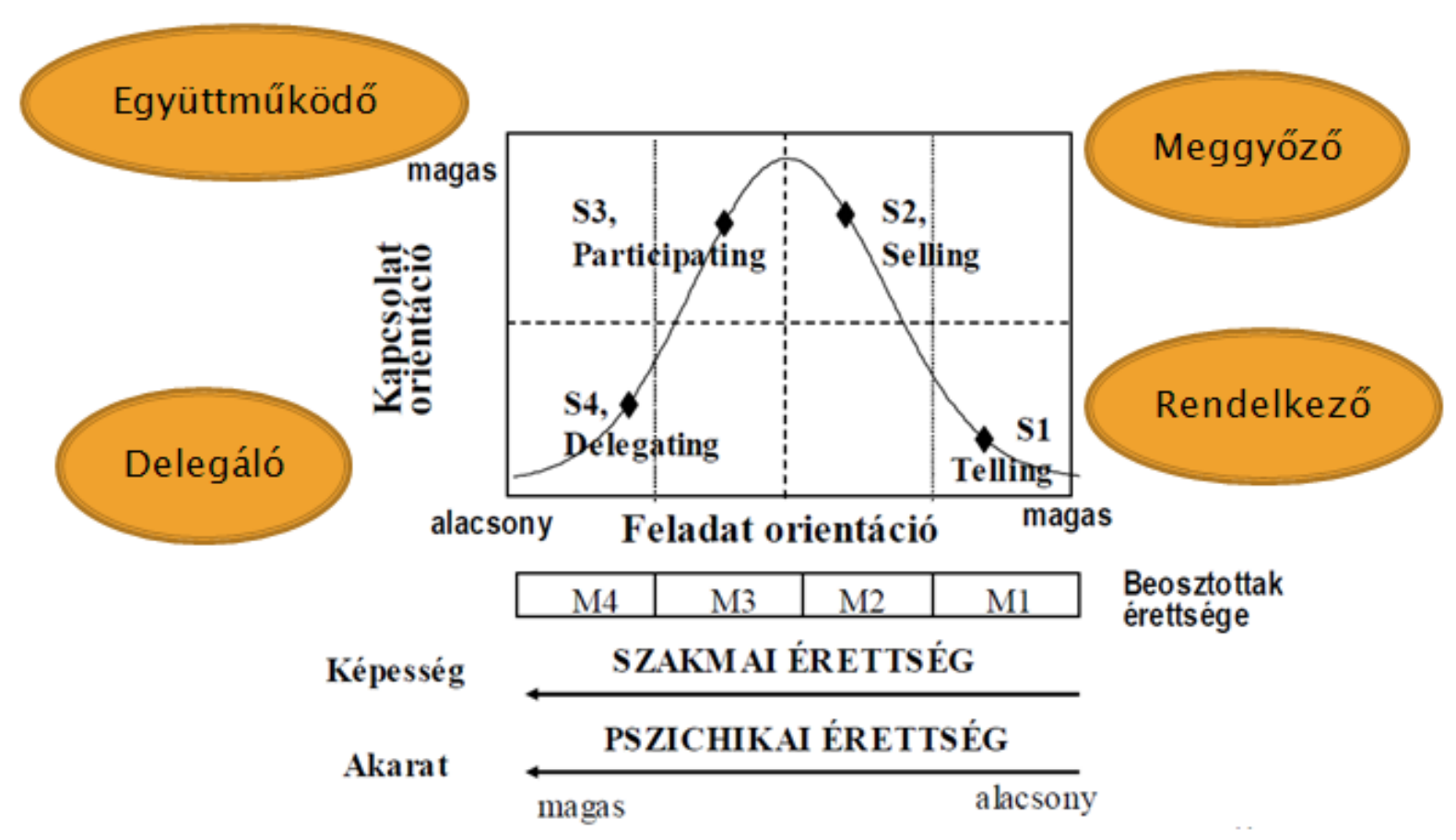

4. ábra: Hersey és Blanchard (1982) szituációs modellje

A modell olvasásakor képzeletben felfelé irányuló függőleges vonalat kell húzni a beosztottak jelölt érettségi szintjétől (M1: éretlen - M4: érett) a görbéig. A metszéspont adja a modell által javasolt vezetési stílust.

\section{Vezetési stílus - szerep vagy személyiségjegy?}


Az általam „klasszikus” vezetési stílusmodellekként megnevezett, eddigiekben bemutatott stílusok kapcsán joggal merül fel a kérdés, hogy a vezetési stílus a személyiségben mélyen gyökerező vonás-e avagy választott viselkedésmód, szerep? A személyiségközpontú stílusmodellek már megnevezésükben is sugallják a választ: a vezetési stílust a személyiség határozza meg. A Michigani Egyetem modellje, miszerint a vezető stílusa vagy csak feladatcentrikus, vagy csak beosztottcentrikus lehet, szintén a stílus alapvető determináltságát sugallja. Fiedler egyértelműen érvel amellett, hogy a vezetési stílus a személyiség által meghatározott jellemző, s nem tartja lehetségesnek a vezető szituációhoz alkalmazkodó stílusváltását.

Más modellek, így Vroom és Yetton valamint Hersey és Blanchard elmélete kifejezetten a vezetési stílus változtatásának képességére épül. Kontingencialista modelljeik egyfajta iránytúként szolgálnak a vezetők kezében, segítve őket annak eldöntésében, hogy milyen vezetési stílust alkalmazzanak különböző helyzetekben.

Az látszólagos ellentmondást azzal lehet feloldani, ha elfogadjuk, hogy mindkét megközelítésben van igazság. A vezetési stílus nem tekinthető kizárólag a személyiség által meghatározott, változtathatatlan jellemzőnek, ugyanakkor a vezető sem tekinthető pusztán elvárt szerepeket, „vegytisztán” előállított tudományos vezetési stílusokat betöltő „bábnak” (Bakacsi, 2001).

\section{A vezetési stílust formal belső és külső tényezők}

Mindezt úgyis megfogalmazhatjuk, hogy a vezetési stílusra belső és külső tényezők egyaránt hatnak. Belső tényezőknek tekintem a vezető személyétől elválaszthatatlan jellemzőket - például a személyiséget vagy a vezető nemét, külső tényezőknek pedig a vezető szűkebb és tágabb környezetéhez köthető elemeket: beosztottak jellemét, érettségét, a szervezeti kultúrát, az ország kultúráját, amelyben a szervezet működik, stb.

Számos kutatás irányul annak felderítésére, hogy a vezetők milyen vezetési stílusokat alkalmaznak és miért.

A vezetési stílusokat egybevetve McGregor (1966) híres tanulmányában megfogalmazott elméletével logikus következtetéseket vonhatunk le a vezetési stílus és a vezető beosztottakról való gondolkodása kapcsán.

McGregor tanulmányában két olyan előfeltevés-rendszert ír le (X és Y), amely a vezetők lehetséges gondolkodását tükrözi beosztottjaikról. Az X elmélet szerint a munkavállalók lusták, ha tehetik, kerülik a munkát. Ebből következően nem szívesen vállalnak felelősséget, kerülik az önálló döntéshozást, s így folyamatos irányításra, szoros ellenőrzésre szorul munkájuk; kizárólag anyagi eszközökkel lehet őket motiválni. Az Y elmélet ennek homlokegyenest ellentmond: eszerint az átlagember számára természetes és kívánatos része az életnek a munkavégzéssel járó fáradozás, szívesen vállal felelősséget megfelelő körülmények között, kreatív, és a jól kialakított szervezeti célokat magáévá téve nem kizárólag anyagilag motiválható a kitartó, felelősségteljes munkavégzésre.

Véleményem szerint joggal levonható következtetés az, hogy az a vezető, aki beosztottjairól az X elmélet szerint gondolkodik, hajlamosabb lesz autokratikusan vezetni, hiszen úgy látja, hogy 
beosztottjai, ha tehetnék, nem is dolgoznának; így messzemenőkig szükségesnek tartja a részletes feladatkiadást, a folyamatos ellenőrzést, esetlegesen a büntetést/jutalmazást. Ezzel ellenkezőleg, ha a vezető úgy látja, hogy beosztottjai nem idegenkednek a munkától és a felelősségvállalástól (Y elmélet), hajlamosabb lehet nekik nagyobb teret engedni a munkavégzésben, lazább ellenőrzést fenntartani és bevonni őket a döntéshozatalba - tehát demokratikusabban vezetni.

Dienesné és Berde (2003) a vezető személyiségén túl a beosztottak szakképzettségét, a szervezet jellegét és a vezető beosztottakkal való kapcsolatát nevezik meg, mint főbb stílusalakító tényezőket. Bemutatják, hogy minél szakképzettebbek a beosztottak, annál inkább érdemes demokratikusan vezetni. A szervezet jellegét illetően elmondják, hogy a különböző katonai, félkatonai, és egyéb hierarchikusan kialakított struktúrában autokratikusabb vezetési stílus az elterjedtebb, s egyben a szervezet jellegére való tekintettel az indokoltabb is, míg például oktató-kutató intézmények esetén célszerű demokratikusabb stílust alkalmazni. A vezető és a beosztott között fennálló viszony is lehet alakító tényező: baráti, informális kapcsolat esetén a vezető inkább hajlamos demokratikusan vezetni, míg formális, távolságtartó kapcsolat esetén lehet autokratikusabban vezetni.

Parry (1996) eredményei alapján a vezetési stílust inkább a képzettség (vezető iskolai végzettsége), mint a tapasztalat befolyásolja - a magasabb végzettséggel rendelkezők hajlamosabbak demokratikusan vezetni. Ugyanez a tanulmány kimutatja, hogy egy adott ország vezetőinek általános (legtöbbjükre jellemző) stílusa összefügg az ország gazdasági fejlettségével - a fejlettebb országokban több a demokratikus stílusú vezető, míg a fejlődő gazdaságokban jóval több az autoriter vezető.

Kocher et al. (2013) összefüggéseket mutatott ki bizonyos preferenciák és a választott vezetési stílus között: azok a vezetők, akik szervezeti munkájuk során a hatékonyságot tekintik elsődlegesnek hajlamosabbak autokratikusan vezetni; a csoport által választott vezetők inkább demokratikusak, mint a „kívülről” a csoport élére helyezett vezetők és végül a férfi menedzserek gyakrabban alkalmaznak demokratikus vezetési stílust, mint női társaik.

Mullins és Schoar (2016) rámutatnak, hogy a családi vállalatok vezetői hierarchikusabban építik fel szervezeteiket és fenntartják a status quo-t; sokkal inkább, mint azok a menedzserek, akik nem saját tulajdonukat irányítják.

Chapman (1975) a nők és a férfiak által alkalmazott vezetési stílusokat kutatva kimutatta, hogy a nők inkább vezetnek kapcsolat orientáltan, mint a férfiak; továbbá a nőkre jellemző, hogy a férfiaknál jobban meg akarnak felelni különböző társadalmi szerepelvárásoknak, mint férfi kollégáik.

Jain és Prekumar (2010) cikkükben kiemelik azt a gondolatot, miszerint: „a vezetési stílusok kultúráról kultúrára-, s adott kultúrán belül iparágról iparágra változnak." 


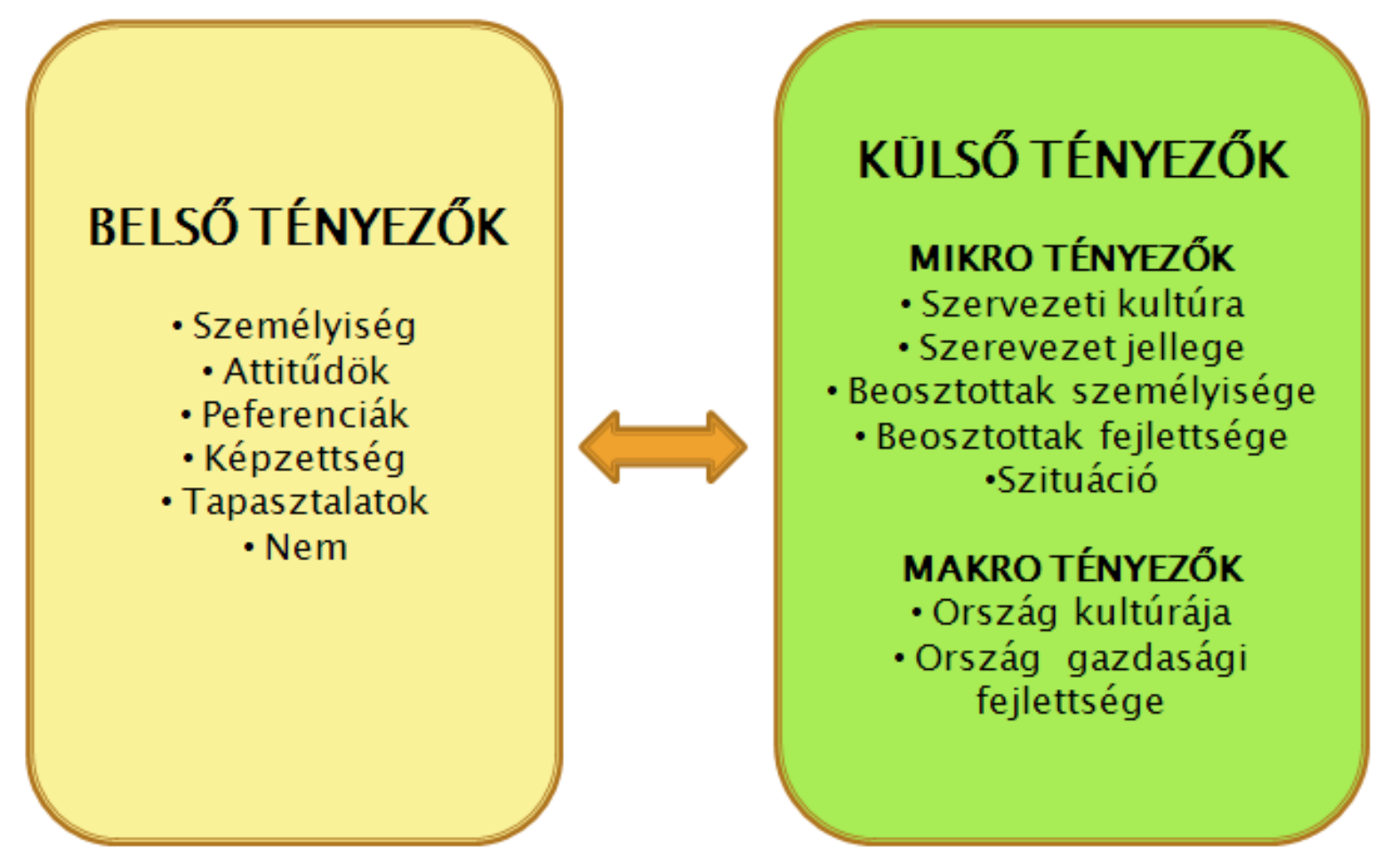

5. ábra: A vezetési stílusra ható belső és külső tényezők

(Forrás: saját ábra)

Az ábrában szereplő felsorolás nem tekinthető teljesnek, hiszen a stílusra ható tényezők felderítése folyamatosan zajlik. Az ábrán szereplő „szituáció” címszó alatt értem mindazokat a speciális külső környezet által meghatározott mikro tényezőket, melyek befolyásolják a vezetési stílust, $\mathrm{s}$ részben megjelenítésre is kerültek az egyes, eddig bemutatott modelleknél: a vezető és a beosztottak viszonya, a feladat struktúráltsága, a vezető hatalmának forrása, stb.

\section{6. Újabb vezetési stílusmodellek}

\section{1. Üzletkötő és átalakító vezetés}

Habár az üzletkötő és átalakító vezetés nem kifejezetten stílustipológiák, mégis érdemes bemutatni ezt az elméletet, hiszen paradigmaváltást jelent, s megértése segítségül szolgál más - részben az itt következő -, stílustipológiák jobb megértéséhez.

Az üzletkötő és átalakító vezetés között lényeges, szemléletbeli különbség van. Az üzletkötő vezetés lényegében az eddig bemutatott vezetési stílusok mind idetartoznak - esetén a vezető beosztottjait azok belátható érdekei mentén szólítja meg, motiválja az eredményesebb munkavégzésre.

Az átalakító vezetés esetén a vezető arra törekszik, hogy saját és beosztottjai érdekei összeolvadjanak. Az átalakító vezetés során a vezető és a vezetett is „átalakul”, az egyének elszigetelt céljai egybeolvadnak a szervezeti célokkal. Az átalakító vezető növeli a követők tudatosságát a szervezeti célok és azok elérésének mikéntje tekintetében. Karizmatikus személye által ráveszi beosztottjait a 
szervezet céljainak belső célokká emelésére, ezáltal megváltoztatva, magasabb szintre emelve motivációs szintjüket.

\subsection{Férfias és nőies vezetési stílusok}

Ahogyan a bevezetőben már rámutattam, a vezetés hagyományosan pozíción és a tekintélyen, gazdasági, politikai és katonai tényezőkön alapult, a tevékenység vezérelve pedig az érdekérvényesítés volt (Purebl, 2013). Ezzel, s persze a hagyományos társadalmi renddel összhangban a vezetők hagyományosan férfiak voltak, helyesebben a férfiak közül is a legkiválóbbak. Nem is lehet kérdéses, hogy a jó vezetôt a „hagyományos” felfogás szerint tipikusan maszkulin jellemzőkkel írták le: lendületesség, objektivitás, versenyszellem, ellentmondást nem tűrő viselkedés (Wajcman, 1998 és Purebl, 2013). A férfias stílusúnak tekintett vezető domináns, hierarchikus szervezeti formában teljesít jól, a jó teljesítmény elérését a feladatok és hatáskörök megfelelő elhatárolásával látja biztosítottnak, a beosztottjait a versenyszellem alapján motiválja (Purebl, 2013).

Az utóbbi két- három évtized gazdasági változásai hatására került előtérbe a „nőiesnek” nevezett vezetési stílus, amely az előbb bemutatott, férfias személyiségjegyekkel operáló férfias stílus ellentéteként a nők jellemvonásait hordozó stílus. A 1980-as években paradigmaváltás kezdődött, annak hatására, hogy az akkori amerikai menedzsment módszerek alulmaradni látszottak a japán módszerekkel szemben (Wood, 1989; Sisson, 1994). Az erőltetetten racionális, túlszabályozott amerikai módszer helyett a figyelem a Japánban széles körben alkalmazott „puhább” módszerekre például erős szervezeti kultúra és elköteleződés - irányult. A puhább stílusokat övező érdeklődés hatására előtérbe kerültek a női menedzserek, akikről feltételezték, hogy a hagyományosan nőkhöz társított jellemvonásokkal bírnak, s így kiváló megvalósítói az újfajta menedzsmentnek. A nőkhöz társított - hagyományosan femininnek tekintett - ilyen jellemvonások az alábbiak: együttműködő, részvételt biztosító, irracionális, intuitív.

Az az elképzelés, ami a nőies stílust kifejezetten a női menedzserekkel azonosítja, megbukott ugyan - a női menedzserek is vezethetnek „férfiasan” és a férfiak is „nőiesen” - (Wajcman, 1998 és Chapman, 1975), a nőies vezetési stílus, mint stíluskategória továbbra is létezik, és változatlan érdeklődés övezi.

A nőies vezetési stílusról elmondható hogy az együttműködés, mint attitűd mentén rendkívül sikeresen funkcionál a „ma” szervezeti környezetében: a kitűnő kommunikációs készsége által a nőies stílusú menedzser könnyen teremt kapcsolatokat, odafigyel a kollégák jó közérzetére, elégedettségére; a jó csoporthangulatot és erős csoportkohéziót a beosztottak részvételének folyamatos biztosításával éri el, konfliktus esetén is a feleket egyaránt meghallgatva, konszenzust keresve igyekszik a rendet helyreállítani. Vezetői munkája során a racionalitásokon túl az intuícióit is figyelembe veszi. 


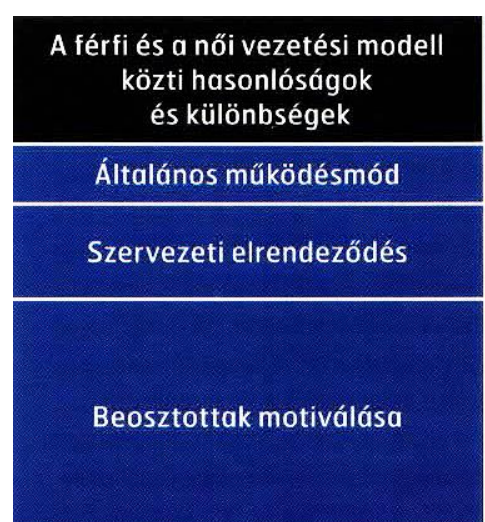

Külsố kapcsolatok

Pozitiv és negativ érzelmek

kifejezése a munkacsoportban

(a konfliktusok felismerésének,

a beosztottak motiválásának fontos eszköze)

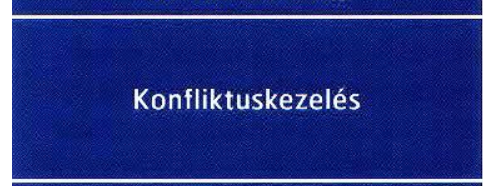

Beosztottakkal való kapcsolat

A hatalomgyakorlás hangsúlya

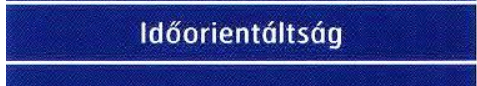

Döntéshozatal

Sikerekhez való viszony

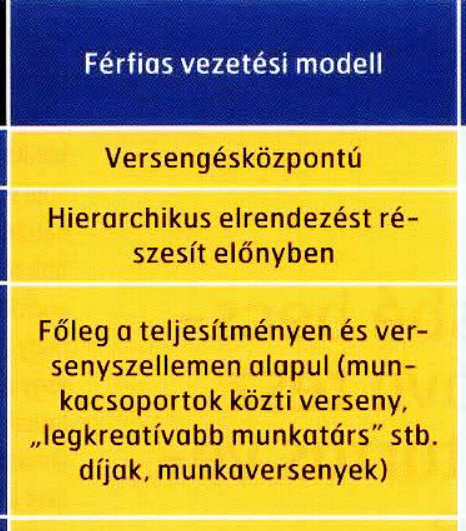

Figyelme föleg a versenytársakra irányul

$$
\text { Kerüli }
$$

Elsősorban pozíció-központú (hatalmi szóval történik)

Személyes kapcsolatát a beosztottakkal nem tartja nagyon fontosnak

A szervezeti struktúrának tulajdonít nagyobb jelentőséget

\section{Jelenorientáltabb}

Dominanciára törekvés, autonómia

Sikereit elsősorban saját vezetői képességeinek tulajdonítja

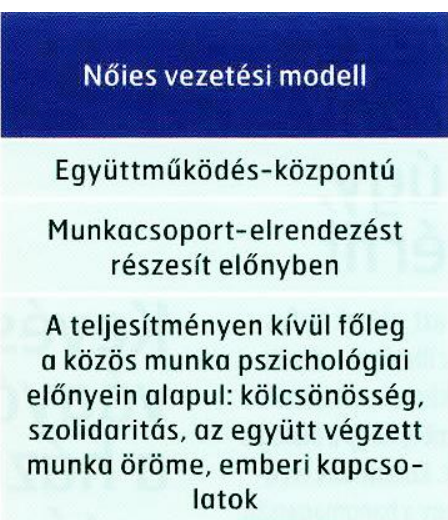

Figyelme fóleg a lehetséges együttmúködésekre és szövetségesekre irányul

Bátorítja

Elsősorban személyközpontú: személyes meggyőzésen alapul, a hatalmi eszközök másodlagosak

Személyes kapcsolata a beosztottakkal központi jelentőségú

A szervezeti kommunikációnak tulajdonít nagyobb jelentőséget.

\section{Jövőorientáltabb}

A döntések megosztására törekvés

Sikereit elsősorban a munkacsoport közös erőfeszítéseinek tulajdonítja

6. ábra: A férfias és a nőies vezetés összehasonlító táblázata

(Forrás: Purebl, 2013)

A férfias és nőies vezetési stílust vizsgálva észrevehető, hogy az előbbiekben bemutatott személyiségközpontú vezetési stílustipológiákkal összefüggéseket mutatnak. A férfias stílus a hierarchikusságával, a hatáskörök és feladatok elhatároltságával hasonlóságot mutat a feladatorientált vezetési stílussal. A nőies stílus ezzel szemben a kapcsolatorientált stílusra hasonlít, amennyiben elsődleges szerepet kap az együttmúködés, a jó csoporthangulat, a konfliktusok megfelelő kommunikációval való feloldása.

Az üzletkötő és átalakító vezetés tipológiapárja közül pedig a férfias inkább az üzletkötő, míg a nőies inkább az átalakító vezetéssel mutat hasonlóságot. 


\subsection{Participatív vezetési stílus}

A participatív vezetési stílus alapja a beosztottak bevonása a döntéshozatalba és a problémamegoldásba, támogatva magas fokú önállóságukat, kezdeményezőkészségüket és kreativitásukat (Rolková - Farkašová, 2015).

A stílus „modern” szemléletet tükröz, abban az értelemben, hogy az előbbiekben már bemutatott „Y” embermodellre épít. A participatív stílusú vezető feltételezi, hogy munkatársai nem idegenkednek a munkától, sőt szívesen veszik, ha nekik nagyobb mozgásteret adnak, ezáltal lehetővé téve kreativitásuk kiteljesedését.

A vezető által alkalmazott participatív vezetési stílus általában a beosztottak munkával való elégedettségének javulását eredményezi (Rolková - Farkašová, 2015). Ez az elégedettség véleményem szerint a megfelelő motiváltságnak köszönhető. Maslow (1966) közismert szükséglethierarchia modellje alapján megállapítható, hogy amennyiben a vezető megfelelő teret ad a személyes tehetség kibontakozásának a megfelelő szintű részvétel és autonómia biztosításával a beosztott legmagasabb szintű szükségletének: az önmegvalósítás szükségletének ad teret.

A participatív vezetési stílusmodell ilyen módon összhangban van az újabb fajta munkamotivációs törekvésekkel. Bullinger és Korge (1999) például azt hangsúlyozzák, hogy a munkavállalók igényeinek megfelelően kialakítva a vállalatokat nincs szükség külső tényezőkkel való motiválásra. A munkavállalók igényeit bemutató tényezők között a szerzőpáros munkájában olyanok szerepelnek, mint: értelmes, kihívást jelentő feladatok; közösen vállalt célok; lehető legnagyobb szabadság; felelősség és a tanulás. A párhuzam ez utóbbi felsorolás, valamint a participatív stílus között könnyen felismerhető.

\subsection{Vezetési stílusok „tárháza”}

Ha abból indulunk ki, hogy egy vezető stílusa milyen nagymértékben függ személyiségétől, hamar ráébredünk, hogy vezetési stílusból jóval több létezik, mint amennyit az itt bemutatott modellek megfogalmaztak. Nem téves tehát úgy gondolkodni, hogy valójában annyi stílus van, ahány vezető.

Ha a külső környezetet tekintjük a vezetési stílus fő alakítójának, szintén hasonló következtetésre juthatunk. Elég gondolatban számba venni a Föld összes kultúráját, éghajlati tényezőjét, természeti kincsekben való ellátottságát, vallását, s így tovább; ahhoz, hogy belássuk, hogy vélhetően számtalan vezetési stílus létezik világszerte, melyeket számtalan féle külső tényező hatására alkalmaznak a világ vezetői.

Jain és Prekumar (2010) cikkükben az alábbi felsorolást használták, a teljesség igénye nélkül:létezik konzervatív stílus, vállalkozói stílus, professzionális stílus, bürokratikus stílus, organikus stílus, intuitív stílus, családias stílus, altruista stílus, innovatív stílus stb.

Cikkemnek a fentebbi gondolatmenet alapján nem lehet tárgya az összes vezetési stílus bemutatása. Jelen bekezdéssel, valamint az iménti felsorolással - cikkem zárásaként - csupán érzékeltetni kívánom 
a vezetési stílusok témájának kimeríthetetlenségét, s a világban tevékenykedő vezetők stílusának a tudományos modellekhez viszonyított sokszínűségét.

\section{7. Összegzés}

A vezetési stílusvizsgálatok a vezetési tevékenység talán legkevésbé kézzel fogható elemére: a vezetők és beosztottak közötti interakciók és viszony megragadására koncentrálnak - nehéz feladatra vállalkoznak tehát. A klasszikus modellek alapvető különbségeket fogalmaznak meg a tipológiák kialakításakor - pl.: hatalomgyakorlás módja, figyelem irányultsága. A klasszikus modellekre építve mára több stílustipológia - mondhatni stílustipológiák tárháza - jött létre. Véleményem szerint nem „túlkapásról” van szó: bármely stílustipológiának létjogosultsága van, amely hozzásegíti adott környezetben, adott feltételrendszerek között a vezetői munka jobb megértését a kutatók számára, illetve a szakmai fejlődést a vezetők számára.

\section{Hivatkozások}

[1] Zs. Antal, M. Dobák (2013), Vezetés és szervezés. Szervezetek kialakítása és múködtetése, Akadémiai Kiadó, Budapest

[2] Gy. Bakacsi (2001), Szervezeti magatartás és vezetés, KJK-KERSZÖV Jogi és Üzleti Kiadó Kft., Budapest

[3] R. R. Blake, J. S. Mouton (1978), The New Managerial Grid, Gulf Publishing, Houston

[4] H. J. Bullinger, A. Korge (1999), Motiváció direkt motiválás nélkül: az alkalmazottak új szemléletű ösztönzése, Humánpolitikai Szemle, 11. évf. pp. 85-91.

[5] B. J. Chapman (1975), Comparison of male and female leadership styles, Academy of Management Journal, 18. évf., 3. sz., pp. 645- 650.

[6] E. Dienesné Kovács, Cs. Berde (2003), Vezetéspszichológiai ismeretek, Campus Kiadó, Debrecen

[7] M. Dobák (2006), Szervezeti formák és vezetés, Akadémiai Kiadó, Budapest

[8] F. E. Fiedler (1980), A hatékony vezetés személyiségtényezői és helyzeti meghatározói, In: PATAKI F.: Csoportlélektan, Gondolat Könyvkiadó, Budapest, pp. 603-644.

[9] P. Hersey, K. Blanchard (1982), Management of Organizational Behaviour: Utilizing Human Resources, Prentice-Hall Inc., Englewood Cliffs, NJ.

[10] R. Jain, R. Prekumar (2010), Management Styles, Productivity and Adaptability of Human Resources: An Empirical Study, The Indian Journal of Industrial Relations, 46. évf. pp. 328344.

[11] A. Kelly, T. Grimes (1993), A menedzsment elvei, Acca Hungaria Kft., Budapest

[12] S. Klein (2002), Vezetés- és szervezetpszichológia, Edge $2000 \mathrm{Kft}$. 
[13] M. G. Kocher, G. Pogrebna, M. Sutter (2013), Other-regarding preferences and management styles, Journal of Economic Behavior and Organization, Elsevier, 88. évf. pp. 109-132.

[14] K. Lewin, P. Lippit, R. K. White (1975), Agresszív viselkedési sémák kísérletileg kialakított társas légkörben, In: PATAKI F. : Csoportdinamika. Közgazdasági és Jogi könyvkiadó, Budapest, pp. 159-191.

[15] R. Likert (1974), Egy érlelődô elmélet a szervezésről, a vezetésről és az igazgatásról, In: ENGLANDER T. : Üzempszichológia, Közgazdasági és Jogi Könyvkiadó, Budapest, pp. 101124.

[16] A. H. Maslow (1966), A Theory of Human Motivation, Psychological Review, July 1943, In: SUTERMEISTER, R. A. : Ember és termelékenység. Közgazdasági és Jogi Könyvkiadó, pp. 85-111.

[17] D. McGregor (1966), The Human Side of Enterprise, In: SUTERMEISTER, R. A. : Ember és termelékenység, Közgazdasági és Jogi Könyvkiadó, pp. 153-171.

[18] W. Mullins, A. Schoar (2016), How do CEOs see their roles? Management philosophies and styles in family and non-family firms, Journal of Financial Economics, Elsevier, 119. évf. pp. 24-43.

[19] S. D. Parry, How 50.000 managers in 15 countries perform, styles/competencies/values. ASTD Internetional Conference, Orlando, Florida

[20] Gy. Purebl (2013), Vezérek és moderátorok: Nemi különbségek a vezetôk között, Mindennapi Pszichológia, 5. évf. 1. sz. pp. 46-49.

[21] M. Rolková, V. Frakasová (2015), The Features of Participative Management Style, Procedia Economics and Finance, 23. évf. pp. 1383-1387.

[22] K. Sisson (1994), Personnel Management, Oxford, Blackwell

[23] R. Tannenbaum, W. H. Schmidt (1966), Hogyan válasszuk meg vezetési módszerünket? In: SUTERMEISTER, R. A.: Ember és termelékenység, Közgazdasági és Jogi Könyvkiadó, Budapest, pp. 354-365.

[24] V. H. Vroom, P. W. Yetton (1973), Leadership and Decision Making, University of Pittsburgh Press, Pittsburgh

[25] J. Wajcman (1998), It's Hard to be Soft, Is Management Style Gendered? In: Managing like a Man. Cambridge, Polity Press, pp. 55-77.

[26] S. Wood (1989), New wave management?, Work, Employment and Society. 3. évf. pp. 379402. 